\title{
Online Peer-Tutoring: A Renewed Impetus for Autonomous English Learning
}

\author{
Tutoría virtual entre pares: un ímpetu renovado para el \\ aprendizaje autónomo del inglés
}

\author{
Herrera Bohórquez, Luis Ignacio ${ }^{1}$ \\ Largo Rodríguez, José David ${ }^{2}$ \\ Viáfara González, John Jairo ${ }^{3}$
}

\begin{abstract}
Challenges to an existing face-to-face peer-tutoring model grew into an opportunity to integrate online technologies as a support for English autonomous learning in two undergraduate teacher education programs at a Colombian public university. This qualitative study examines how a group of tutees' exposure to an online-based peer-tutoring model shapes their autonomy. Informed by data from questionnaires, a focus group interview, tutees' logs, and records of their engagement with the model's internet resources, researchers identified a change in participants' conceptualization of autonomous learning and an impact on their self-directed practices rooted in the immediacy, accessibility, comfort and availability of resources that the online peer-tutoring model favors.
\end{abstract}

Luis Ignacio Herrera Bohórquez is an English teacher at the Smart Languages Academy in Chía (Colombia). He is currently studying for a Master's degree in ELT at Universidad de La Sabana. His research interests include online environments, peer-tutoring, and autonomy. luishebo@unisabana.edu.co https://orcid.org/0000-0002-0102-371X

José David Largo Rodríguez holds a B.Ed, in Modern Languages from Universidad Pedagógica y Tecnológica de Colombia (UPTC). He was part of the Research Network RETELE at UPTC for three years. He is currently a professor at a private institution. His research interests include culture and identity issues in English language teaching. coordinadorlima@t-ingles.com

John Jairo Viáfara González is a professor at Universidad Pedagógica y Tecnológica de Colombia (UPTC). He holds a B.Ed. in education (English), a Master in applied linguistics and a PhD in Second Language Acquisition and Teaching from the University of Arizona. He specializes in pre-service teacher education and is a main researcher in the group RETELE. john.viafara@uptc.edu.co https://orcid.org/0000-0002-8409-6016

Received: December 20th, 2018. Accepted: May 22nd, 2019

This article is licensed under a Creative Commons Attribution-Non-Commercial-No-Derivatives 4.0 International License. License Deed can be consulted at https://creativecommons.org/licenses/by-nc-nd/4.0/ 
Luis Ignacio Herrera Bohórquez, José David Largo Rodríguez, and John Jairo Viáfara González

Keywords: autonomy, online environments, peer-tutoring, online implementation, online English learning.

\section{Resumen}

Los desafíos que enfrentaba un modelo de tutoría presencial entre pares se convirtieron en una oportunidad para integrar la virtualidad al aprendizaje autónomo del inglés en dos programas de licenciatura en una universidad pública colombiana. Este estudio cualitativo examina cómo la exposición a un ambiente de aprendizaje virtual moldea la autonomía de un grupo de tutoriados. A partir de cuestionarios, una entrevista de grupo focal, registros de reflexiones y de uso de recursos de internet, los investigadores identificaron un cambio en la conceptualización de aprendizaje autónomo y un impacto en las prácticas autodirigidas de los participantes como resultado de la inmediatez, accesibilidad, comodidad y disponibilidad de los recursos que el modelo tutoría virtual favorece.

Palabras claves: autonomía; ambientes de aprendizaje en línea; tutoría entre pares; implementación virtual, aprendizaje en línea del inglés

\section{Introduction}

In the last two decades, RETELE research group set out to examine the connection between peer-tutoring and autonomous learning in the context of EFL pre-service teachers. Their work focused on designing a face-to-face peer-tutoring model to support these prospective teachers' education (Viáfara \& Ariza, 2018). Although the model has proven to be beneficial in guiding Colombian EFL pre-service teachers' efforts to work autonomously when learning English (Ariza \& Viáfara, 2009; Viáfara, 2014), a recent diagnosis survey administered to examine debut students' profiles, needs, and interests signaled the emergence of new challenges for the existing face-to-face model. Firstly, the growing demand for tutoring has rendered existing human and logistic resources, provided through the faceto-face model, limited. Secondly, the survey also showed that $71 \%$ of first- and secondsemester students seem to invest less than one or two hours a week in their autonomous work for their four-credit language course. Consequently, their investment in autonomous work falls behind the university's official requirements (five hours weekly for a three-credit course). Thus, there is a substantial gap between the time that surveyed first- and secondsemester students devote to autonomous work practices and the university's expectations in this regard. Thirdly, although the participating students were enthusiastic about engaging in online peer-tutoring and had awareness of the internet resources for autonomous English language learning, our pre-assessment of the target population made apparent that they did not understand how to take full advantage of these tools.

Despite the fact that online peer-tutoring is believed to foster autonomous learning (Dekhinet, Topping, Duran, \& Blanch, 2008; Jones, Garralda, Li, \& Lock, 2006; Liu, 2014), studies focusing on the nuances of participants' cognitive engagement, practices, and 
assessment regarding independent learning ${ }^{1}$ in these collaborative models are scant. In Colombia, although scholars such as Viáfara \& Ariza (2008) along with Cardozo (2011), and Tolosa, Ordóñez, and Alfonso (2015) have designed peer tutoring models to support English language learning, they have not yet involved virtually-mediated sources. The diagnosis survey led us to consider the ubiquitous presence of online technologies and the strong affiliation that university students manifested towards these environments as a plausible option to solve the aforementioned limitations. In this vein, this article examines how a group of tutees shaped their autonomy by being involved in an emerging peer-tutoring virtual model.

\section{Peer-tutoring and English Learning: Basic Concepts}

The collaborative nature of peer-tutoring is rooted in Vygotsky's socio-cultural and constructivist ideas about learning (Clarkson \& Luca, 2002; Verba, 1998). Scaffolding, the "process that enables a child or novice to solve a problem, carry out a task or achieve a goal which would be beyond his unassisted efforts" (Wood, Bruner, \& Ross, 1976, p. 90) is also a conceptual foundation for peer-tutoring. Accordingly, peer-tutoring involves a more knowledgeable or skillful peer (a tutor) who works hand-in-hand with a tutee to potentiate their learning opportunities.

In order to characterize the type of peer-tutoring being conducted in this study, we first needed to underline the asymmetrical nature of this collaborative practice. Tutors and tutees, who can function in one-tutor-to-one-tutee or one-tutor-to-a-group-of-tutees arrangements, exhibit differences in relation to ages, experience, and knowledge (Duran \& Monereo, 2005). Secondly, although the aim of tutoring in this research project was English language learning, a broader view has been embraced, which is not solely linked to the academic realm. This view is that the tutor is not only expected to provide tutees with sources to build their disciplinary knowledge, solve doubts, and increase their metacognitive awareness, but also to encourage tutees' cognitive, emotional-affective, social, and professional growth (Álvarez, 2002; Ariza \& Viáfara, 2009).

Peer-tutoring and online technologies. Educational practices keep being redefined by the advent of new technologies. Computer-Assisted Language Learning (CALL), including Mobile-Assisted Language Learning (MALL), can contribute to understanding new possibilities for peer-tutoring in virtual environments. Peer-tutoring can benefit from the overarching learning conditions that Hubbard (2008) has established in CALL environments, namely learning efficiency, learning effectiveness, access to more resources and interaction, time and location convenience, and motivation.

As a result of their interconnectedness, autonomous learning and independent learning are used interchangeably throughout this document. 
Luis Ignacio Herrera Bohórquez, José David Largo Rodríguez,

and John Jairo Viáfara González

Computer-Mediated Communication (CMC) is also associated with online peertutoring inasmuch as it seeks "to provide alternative contexts for social interaction; to facilitate access to existing discourse communities and the creation of new ones" (Kern \& Warschauer, 2000, p. 13). This purpose of CMC is critical for the collaborative nature of peer-tutoring which enhances not only relationships between tutor and tutee, but also among tutees. CMC capitalizes on the vast array of internet technologies (e.g., messaging, social networking, and online forums). It also differentiates between 'asynchronous' (interaction in which participants are not simultaneously interacting online) and 'synchronous' (real time interaction) (Simpson, 2002).

Published studies on foreign language learning through online peer-tutoring have yielded results on various topics. Wong and Fauverge (1999) found that a collaboration-enhancing context, as well as permanent support, suitable activities, and broadband computer network hypermedia environments fostered learning. Concerning tutees' gains, Jones et al. (2006) determined that more balanced interaction between them emerged in online peer-tutoring rather than in face-to-face peer-tutoring; this could have happened due to tutees' higher empowerment and increase in participation when communicating online. Dekhinet et al. (2008) complementarily showed how internet technology increased tutees' motivation and engagement in learning. Thurston, Duran, Cunningham, Blanch, and Topping (2009) found that tutees' self-regulation, self-confidence, and movement towards autonomy comprised a product of the motivating and comfortable context influenced by the anonymity that online peer-tutoring generated.

In the context of online peer-tutoring, Jones et al. (2006) found that online tutoring may emphasize more on the content, process of writing, and higher order writing skills whereas face-to-face tutoring lacked formal aspects of language use in the participants' exchanges. Dekhinet et al. (2008) reported gains in L2 learners' processing time when negotiating feedback for their writing and in their awareness of limitations through the integration of various communicative skills. Thurston et al. (2009) found that online peer-tutoring enhanced writing practice and fluency in relation to tutors' provision of an invariable type of feedback, which favored tutees' engagement and change in problematic writing features. Finally, Topping, Dehkinet, Blanch, Corcelles, and Duran (2013) established that despite asynchronous interaction comprising a limitation for the quality of feedback in peer-tutoring,

16 the real-life nature of online interactions increased the quality of texts produced due to more feedback for error correction.

Autonomous learning and online environments. Being an autonomous learner has been related to having certain skills; for instance, Holec (1981, p. 3), asserts that autonomy is "the ability to take charge of one's own learning" in order to define the aims, contents, sequence, strategies, and assessment to organize one's own learning. Benson (as cited in Nunan, 2003, p. 194) concurs with Holec and summarizes that autonomous learners' 
capacities are "the most important abilities [...] that allow learners to plan their own learning activities, monitor their progress, and evaluate their outcomes." In a broader pedagogical sense, autonomy leads individuals into processes of critical reflection, taking decisions and acting independently (Little, 1991). In the context of this online peer-tutoring study, autonomy entails more than tutees making free selection of activities and contents; it also refers to the critical and analytical capacity of tutors and tutees to play an active and responsible role in designing learning agendas rooted in learners' needs.

Online technology has been regarded as a robust means to motivate the autonomous learning of foreign and second languages (Warschauer \& Liaw, 2011; Brooke, 2013; Liu, 2014). For instance, Liu (2014) stresses that: "a good combination of modern technologies and learner autonomy is a perfect way to learn English" (p. 25). Brooke (2013) introduces three stand-out perspectives in using technology to nurture autonomous language learning: (1) organizing, self-monitoring, and assessing learning; (2) exercising cognitive skills through involvement in online social interaction and reflection upon language practice; and (3) employing online facilitators by developing communities, discovering learning, and offering feedback.

Research examining online resources and language-skill and knowledge development in autonomous frameworks includes Miyakoda, Kaneko, Ishikawa, Shinagawa's (2010) study which found that visual and aural data coupled with text data led participants to higher retention of vocabulary meaning in contrast to pen-and-paper strategies. Wong (2011) concluded that showing awareness of their needs and choosing learning methods and materials were characteristics in students who developed a more concrete approach to learning autonomously. Furthermore, willingness to develop autonomous work led participants to their development of better writing skills. Cheng's (2017) study integrated autonomous English language learning and a project-based learning platform to determine that this environment seemed to encourage participants' enthusiasm, interest, leadership, and thinking skills.

\section{The Study}

This study aligns with a qualitative approach to research. It focuses on understanding a target phenomenon from the different perspectives of those involved in the study by contextualizing issues in their socio-cultural-political milieu (Glesne, 2006) as well as impacting learning conditions. Considering that this study sought to improve learning practices by means of an online peer-tutoring model, which guided instructors into collecting, organizing, and analyzing data to examine autonomous practices, it is defined as an action research study (Ary, Jacobs, Sorenson, \& Razavieh, 2008). 
Luis Ignacio Herrera Bohórquez, José David Largo Rodríguez, and John Jairo Viáfara González

Participants. The final group of participants was composed of five females and three males, who were enrolled in two English teacher education undergraduate programs at a public university. They came from Boyacá, Santander, Meta, and Cundinamarca departments. Their ages ranged from 17 to 19 years and their English levels ranged from basic to preintermediate, according to the English course they were taking. Graphic 1. Summarizes their characteristics.

These eight tutees and no others were selected randomly to assemble the final group of participants considering the enormous amount of data that this study collected from a larger group of 26 users who employed the online peer-tutoring model.

Instruments and procedures for data collection. Researchers employed two questionnaires, one prior and one subsequent to their involvement in the peer-tutoring model. These questionnaires were piloted with former tutees who had previously partaken in the face-to-face model and whose profile characteristics and previous experience would align with the characteristics of the targeted users of the online model in order to test the questionnaires and make necessary adjustments to their design. These two questionnaires had the aim of gathering the participants' perceptions and descriptions of autonomous English language learning practices prior to and after the implementation. The first questionnaire was divided into four sections related to the participants' learning profile, namely, their learning preferences and factors that influenced their learning, their use of the internet for language purposes, their autonomous work and their perceptions about a possible online

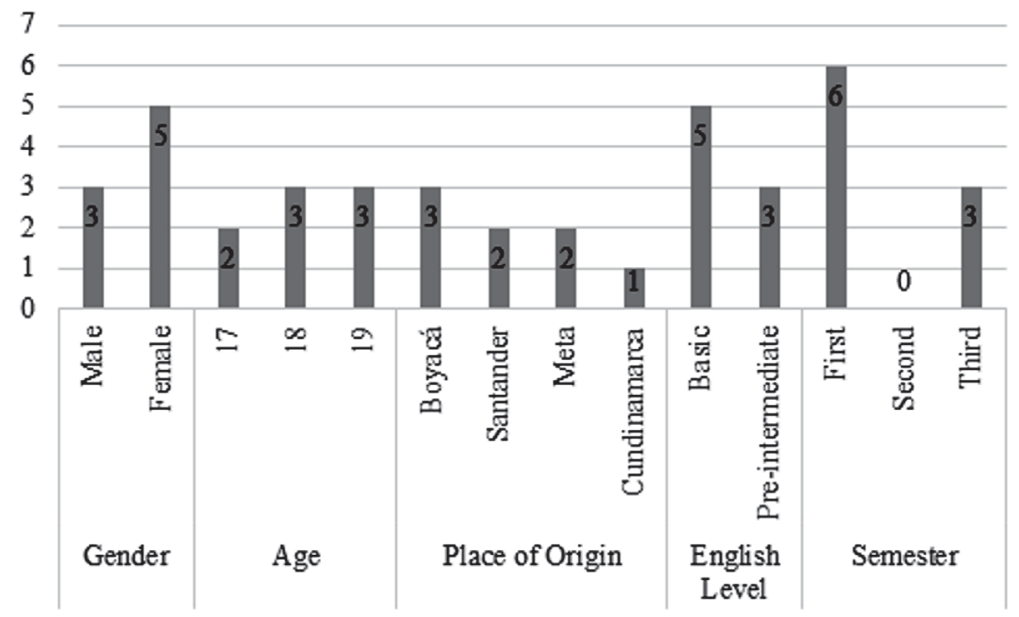

Graphic 1. Participants' characteristics and profile. 
implementation of the face-to-face model. The second questionnaire was divided into 3 sections: development of language skills, autonomous learning within the online peertutoring model, and their work with the internet resources of the model. Both questionnaires were administered through an internet application.

The second data collection instrument was a focus-group interview. This 90-minute focus group allowed researchers to flesh out data elicited through the questionnaires concerning the participants' autonomous English language learning as they employed the online peer-tutoring model. The participants' contributions were audio-recorded by means of a cell phone application.

The participants' learning logs became the third data collection technique. The participants kept records of the activities they were developing throughout their involvement in the experience. In the records, they reflected upon their views about their autonomous learning, use of the online resources, and personal development of English language abilities. Logs were sent to the researchers via email every two weeks. Valuable data were also collected from the participants' interaction in the online applications of the model. Those applications were the WhatsApp chats, Skype video calls (tutoring), Facebook chat, and the peer-tutoring web page. More information about these online tools is provided in the next section about the online peer-tutoring model. Table 1 below depicts the number of logs, chats, video calls, and online-Skype tutoring sessions obtained from each participant.

The online peer-tutoring model. Peer-tutoring in this study was based on a faceto-face model originally designed by Viáfara \& Ariza (2008) to buttress the autonomous learning of English. Figure 1 below illustrates how the model was adapted to integrate Internet resources in each of its stages.

The cycle starts when tutees join a tutorial session with the purpose of addressing either (1) immediate needs or (2) working on a personal improvement plan ( $\left.\mathrm{PIP}^{2}\right)$. WhatsApp and Facebook chats support tutor and tutees encounters granting immediate and permanent access to online feedback concerning difficulties and doubts about the target language. The second stage comprises the development of Skype-based tutorial sessions. Through video conferencing, the participants could join tutors and other tutees with the purpose of working on language practice, reflection, and learning how-to-learn activities. Sessions involve one to six participants in video conferencing. The research group's website integrated links for selfaccess language practice and information regarding English language use and form, so tutees could have several options to resolve language learning doubts. There were also guidelines to learn how to learn. Finally, reflection chats were held through Facebook to serve peer- and

2 PIP: Personal Improvement Plan is an autonomous practice developed by the students at the University where the study took place. Students are to plan and engage in autonomous practices to buttress their communicative abilities in the foreign language. 
Luis Ignacio Herrera Bohórquez, José David Largo Rodríguez, and John Jairo Viáfara González

Table 1. Record of Participants' Involvement in Online Peer-Tutoring Model Spaces.

\begin{tabular}{|c|c|c|c|c|c|}
\hline $\begin{array}{c}\text { Participant } \\
\text { Space }\end{array}$ & $\begin{array}{c}\text { WhatsApp } \\
\text { Practice-Doubts } \\
\text { Chats }\end{array}$ & $\begin{array}{c}\text { Facebook } \\
\text { Practice } \\
\text { chats }\end{array}$ & $\begin{array}{c}\text { Facebook } \\
\text { Reflection } \\
\text { Chats }\end{array}$ & $\begin{array}{c}\text { Skype } \\
\text { Tutoring } \\
\text { Sessions }\end{array}$ & Logs \\
\hline P1 & 5 & 4 & 0 & 6 & 3 \\
\hline P2 & 4 & 0 & 1 & 5 & 4 \\
\hline P3 & 3 & 3 & 1 & 5 & 3 \\
\hline P4 & 3 & 1 & 0 & 5 & 3 \\
\hline P5 & 4 & 1 & 0 & 6 & 4 \\
\hline P6 & 2 & 1 & 0 & 6 & 3 \\
\hline P7 & 6 & 2 & 1 & 6 & 3 \\
\hline P8 & 3 & 0 & 0 & 6 & 3 \\
\hline
\end{tabular}

Participants' names have been codified using the letter P, which stands for Participant, followed by the number that labels each participant.

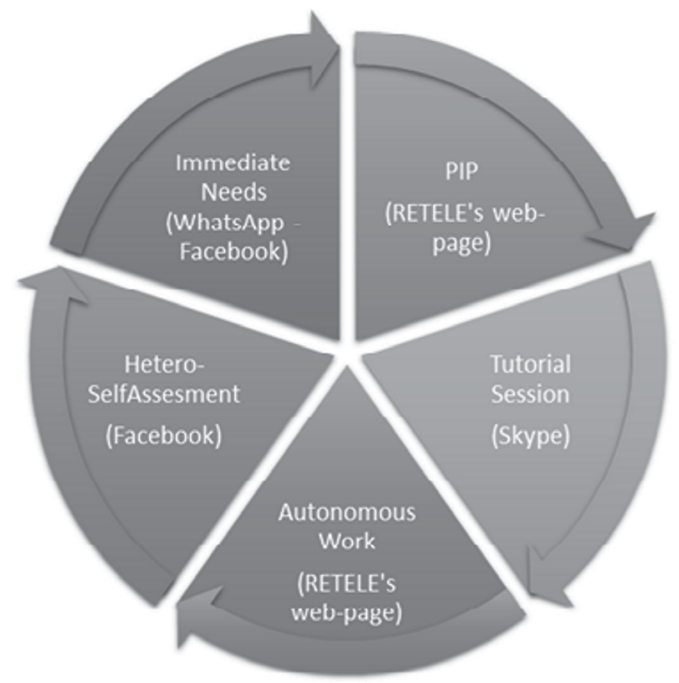

Figure 1. Online peer-tutoring model (Adapted from Viáfara \& Ariza, 2008). 
self-assessment purposes. In this space, the tutors proposed common topics to reflect on language learning or autonomous work. A new cycle started after another tutee went back to a new tutorial session with newer perspectives.

Data analysis. Grounded Theory principles (Glasser \& Strauss, 1967) were followed to analyze data. Accordingly, data were analyzed using coding techniques, namely reading the data several times and making comparisons among codes. This allowed the researchers to establish significant patterns and relationships among data. Subsequently, the researchers used recurrent patterns to build the categories that would answer the research question of the study. Findings were corroborated by doing both researcher and methodological triangulations (Patton, 2001).

\section{A Renewed Impetus towards Autonomy in English Learning}

The next section illustrates how the online peer-tutoring model seemed to have influenced the participants' way of thinking and acting at different levels concerning autonomous learning.

Self-discipline, collaboration and motivation as pillars to a new conceptualization of autonomy. By the end of the peer-tutoring experience, participants seemed to have updated their concept of autonomy. When asked in the final questionnaire, if after participating in online peer-tutoring, they had transformed what they understood as autonomy, seven of them said they had. They explained that their self-perceived change was related to clarifying the concept, moving from theory to practice, acting more consistently with what autonomous learning implied and connecting the concept with their expansion of opportunities and spaces to facilitate self-directed learning. The only student who reported no change in his understanding of what autonomous learning encompassed explained that he had always conceived autonomous learning as building a self-improvement plan, but he had not practiced it.

Consequently, the participants showed a more complex and nuanced notion of what autonomous learning embraces. For instance, whereas before this implementation, Participant 4 characterized autonomy as ".... the work that each person does on his own initiative with the aim of improving in some aspect of his life" (P.4- Q1), at the end of this study, she indicated that "autonomous work involves a lot of dedication, persistence and perseverance, is to work with discipline, seeking to grow up day by day" (P.4-Q2). Participant 4 refined her notion of autonomous learning by incorporating elements such as discipline, dedication, persistence and perseverance, which can be related to learners' psychological need to feel comfortable when working autonomously. Ryan, Kuhl, and Deci (1997) posit that meeting learners' psychological needs 
Luis Ignacio Herrera Bohórquez, José David Largo Rodríguez, and John Jairo Viáfara González

may facilitate precisely student's persistence, performance, and learning, having a positive effect on the growth and well-being of the individual.

Similarly, prior to this implementation, Participant 7 defined autonomy as "... a method of individual study that is performed overtime" (P.7-Q1). Nonetheless, within the second questionnaire, Participant 7 remarked that "to learn autonomously is to create that self-discipline that will help us later when finding a job or continue studying" (P.7-Q2). The two excerpts illustrate Participant 7's move to conceptualizing autonomy; his new understanding did not allude to the term "method" and is rooted in his perseverance and self-control over learning, leaving aside the expectation of external support to achieve that autonomy. This concept modification aligned with Little (2007) and Taylor's (2006) explanation of autonomy as an ability encompassing responsibility, persistence, and self-discipline towards one's own learning and goal-oriented action plans. Similarly, Participant 7's emphasis on the advantage es that working autonomously may have concerning long-term goal-achievement concurred with Deci and Ryan's (1995) discussion of how learners are intrinsically motivated to learn autonomously. Participant 7's more robust conceptualization of autonomous learning seemed to be articulated with his actual self-directed practice. Data show that this student voluntarily participated in the majority of Skype sessions (6 out of 7 ) as well as in two out of three practice chats.

Collaboration emerged as another prominent notion that the participants integrated into their updated understanding of autonomous work. A general tendency in the participants' answers in the initial questionnaire was to define autonomous learning as a companionless endeavor; however, after their involvement in virtual peer-tutoring, some of them apparently set aside the idea of individual work as a primary condition for autonomy:

I believed that autonomy is what I used to do alone without nobody's help... Now I think that it would be better to develop a personal improvement plan and develop it day by day, from the activities that I like and to relate it to what I want to learn. (P.1-L.2)

At the end of the experience, Participant 1 expressed that there were more relevant aspects to highlight about what autonomous learning entailed than the idea of working by yourself; she referred to psychological states, commitment, extracurricular work, and one's own organization of learning.

Data informed us that not only did some of the participants rethink the idea of autonomy in English learning as a solitary enterprise, but that they expanded their notion to include collaboration with peers as a key element. Participant 1 continued:

My perception of autonomous work has changed. Before I thought it could mean working for and by one's self, over time we realize that, like everything else, it is a work that can also be collaborative from which one learns from others' mistakes..." (P.1-L2) 
As Participant 1 mentioned in her second log, interacting with peers allowed her to build knowledge from their limitations as they can realize each one's needs, and they can work together to fulfill or satisfy them. In fact, while involved in the online peer-tutoring model, the participants favored those spaces in which they were given the opportunity to socialize with others. The online environment encouraged them to form groups and networks. They seemed to benefit from peer-support and felt confident among their own learning community, as Participant 8 pointed out: "As far as there is confidence, and we have a sort of a group, we knew each other, then it is easier the interaction" (P.8-9'10). Participant 3 also mentioned that:

In general Author's research group offered a lot of tools, it was great because it did not take the tutorials over an academic perspective, but a social space in which we could interact, break schemes, share with partners and other people, and know about culture. (P.3-16'03")

Although the concepts of learner independence and autonomy are commonly mistaken as solitary learning, Murphey and Jacobs (2000), for example, posit that the term autonomy does not necessarily imply studying alone, or as Godwin-Jones (2011, p. 6) states, "secluding oneself in a cork-lined room with a mountain of learning materials." Concerning online environments, Snodin (2013) concurs with the previous scholars by conceiving autonomy as a process involving interdependence among partners instead of separation. This occurs because these environments generate a comfortable atmosphere that encourages students to interact and help each other as their affiliation with language learning and autonomy grows. Likewise, Simpson (2002, p. 415) explains that CMC "provides valuable alternative spaces for collaboration and opportunities for learner autonomy."

Motivation becomes the last innovating element identified in the participants' conceptualizations of autonomous learning. In this vein, two participants conceived autonomy as an intrinsic-motivation booster, which led them to perceive autonomy as a joyful practice rather than an external imposition. At the onset of the experience, Participant 1 defined autonomy as "to work and improve the limitations so we clearly and deeply know of ourselves." By the end of the experience, Participant 1 explained her new concept: "More than obligation, working autonomously is to realize about your drawbacks, so that you can work day by day to improve them, because you like to do it' (P.1-L3). Although she maintained her idea about autonomy being related to overcoming limitations, she included a new element: motivation.

Three other participants intertwined autonomous learning with the motivation they built to research on issues of their interest, practice the language, and show themselves what they could achieve:

We were encouraged more than everything to research if eh ... in that sense one felt interested to know eh... how to express the same idea differently. Something that I highlight is that we were motivated to, in a way, show the things that we do, not to the tutor, not to Author but to oneself. (P.3-34'37') 
Luis Ignacio Herrera Bohórquez, José David Largo Rodríguez,

and John Jairo Viáfara González

The aforementioned findings concurred with Garrison's (1997) and Benson's (2007) association of autonomous learning with the motivation that learners should develop to become responsible for their own learning. Likewise, Spratt, Humphreys, and Chan's (2002, p. 262) study found that "there was a strong relationship between higher levels of motivation and greater engagement in outside class activities." Their participants constantly reported that when they were not motivated, their autonomous work was limited.

Building a concept about autonomy closely attached to motivation seemed to correlate with the enthusiasm that the participants experienced as a result of their experimentation with the online peer-tutoring model:

All these activities motivate us to practice autonomously as it gives us new horizons or approaches to English, and to relate it (autonomous work)) to topics of our interest, I was usually looking forward to considering the topics worked on the tutoring and developing them more in my free time. (P.8-L.2)

Because of the myriad of internet resources provided by the model, the participants found themselves being more likely to promptly continue learning English; thus, enhancing positive attitudes towards learning the language. In addition, they felt empowered to look for different and newer ways to develop their own independent practices. The next section delves deeply into these tutees' autonomous language learning practices as users of the model.

The participants' engagement in autonomous learning: The mediation of the online peer-tutoring model. The online peer-tutoring model was not only a new way of thinking, as described above, but it also had an impact on participants' autonomous English language learning. Overall, the participants ranked the perceived impact of this model in their autonomous practices as high (three students) or very high (five students) (Q2). When being asked to elaborate regarding the high scores they provided, the participants observed that, as a result of this experience, their eagerness for learning had transcended their classroom and even tutoring spaces: "I have increased my interest for autonomous learning working in different spaces from tutoring" (P.2-Q2). In this regard, they sometimes continued exploring topics initiated with their tutors. A common answer was "Despite tutoring, I dedicate a lot of time to research on grammar and pronunciation" (P.3-Q2). Another participant remarked: "It [RETELE's research group online implementation] has had a high impact because through the online spaces, I have been able to explore different tools that provide advantages when it comes to practicing 24 English" (P.2-Q2).

The aforementioned testimonies from the participants aligned with scholars' examination of learning through peer-tutoring mediated by online technologies and the development of autonomy in learning buttressed by Web 2.0. In the first case, Dekhinet (2008) shows how Internet technology increased students' motivation and engagement. In a second study of the kind, Sutrisno (2016) found that students' language knowledge and skills were fostered by their participation in the online community. 
One of the autonomous decisions that the participants made concerning their engagement in language practice involved the time they spent working on online tutoring. When comparing data from the first and second questionnaires, some of the participants' reports showed a slight increase in the time they devoted to self-directed learning. Accordingly, two participants claimed that their autonomous work increased one hour per week: while one emphasized that her interest in going deeper into topics studied in tutorial sessions fostered her autonomy, the other underlined her motivation as a powerful source to engage herself in independent work. Two other participants, who invested less than one hour before their engagement in online peer-tutoring, informed us that they were then investing one hour by the end of their participation in the study. The first of these two participants commented: "I do not devote enough time because I need to do other things but compared to the previous semester, it [my autonomous work] was better because I really worked autonomously" (P.1-Q2). The second expressed that, due to time constraints, one hour was the most she could devote.

These two participants' answers indicated that they reduced their independent work; one went from six hours to two hours while the other worked one hour less by the end of the study. One referred to time constraints as the reason for this decline whereas the other commented that she divided her time between face-to-face and online tutoring. Two other participants did not report any change.

Another layer intersecting the participants' self-directed practices referred to them as being immersed in the virtual spaces offered by the model for their autonomous work:

It is very little time the one I devote to improve my skills, I merely do the tasks [from regular courses] and I forget how important working autonomously is. Tutoring has become the little extra work. I do to improve my English. (P.1-L3)

Even though the participants were offered multiple spaces to learn through the Internetsupported model, within the second questionnaire, the participants asserted that they seemed to be more engaged in working on some online spaces such as the virtual tutorial sessions, doubts chats, and the web page rather than on others, namely, reflective and conversation practice chats (See Graphic 2).

As Graphic 2 shows, the participants ranked their preference for Skype Tutoring among very high and high, whereas a more diversified ranking was offered to other spaces. Doubts chats or reflection chats, and Author's webpage, were ranked among high, medium, low, or very low. On this matter, some of the participants affirmed that their low or very low participation in some of these spaces was due to their lack of time, interest, or confidence in participating: "The main reason why I did not participate in the reflection chat was because of time and confidence... in relation to Skype tutoring I always tried to participate because they seemed very meaningful to me" (P.8-Q2). Another participant mentioned that: 
Luis Ignacio Herrera Bohórquez, José David Largo Rodríguez, and John Jairo Viáfara González

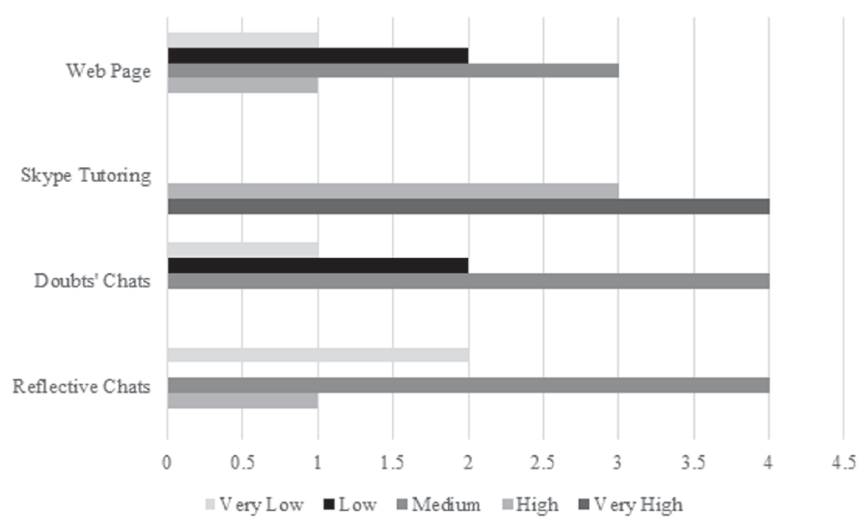

Graphic 2. Students' perceived participation in the different spaces of the virtual model.

I had good participation in the virtual tutorials [Skype] because they are quite interesting but in relation to the doubts chats, the web page, reflection chat what happened was that I did not care and that I did not take advantage of the resources. (P.4-Q2).

In addition to the previous factors, data showed that the participants' tendency to favor certain online tools more than others in their autonomous learning was related to the characteristics of the virtual environment associated with immediacy, accessibility and comfort, and resources to learn. Accordingly, Tomes (2001) describes among the benefits of CMC, the possibility for these kinds of new technologies to overcome the limits of distance and time, which make possible collaboration and learning that in some other cases could not take place.

The participants claimed that immediacy became a factor in fostering their autonomous language learning because through WhatsApp and Facebook chats they gained expeditious support to resolve doubts. The analysis of these chats showed that the participants' queries were solved in no more than five to ten minutes. In the same line of thought, they reported that simultaneous interaction in tutorial sessions via Skype permitted a process of immediate feedback and counseling regarding language skills while they worked with their tutor. As a result of this immediacy, some participants claimed that they enhanced their English language skills: "The answers to all our questions were always resolved in a short time and that showed interest in us. Then we started writing or talking in a better way because we felt the support of someone." (P.1-Q2)

Accessibility and comfort were related to the participants' engagement in self-independent learning inasmuch as they expressed that they could have access to virtual tutorial sessions at anytime and anywhere. The online peer-tutoring environment enriched their practice as they easily approached materials, activities, or any application of the model from convenient locations where Internet and technological devices were available: 
These spaces [RETELE's research group virtual spaces] allow us to clear doubts and learn from anyplace we are at, if we have access to the internet" (P.7-Q2).

It [Peer-tutoring model] is good due to the fact of time, I do not have to go from one place to another, and therefore I favor the virtual tutorials by the comfort that they offer. (P.6-25'30")

Finally, the participants reported that the resources of the online peer-tutoring model buttressed not only their autonomy to work on their language abilities but also their opportunities to learn how to learn. The participants also seemed to be interested in new ways of approaching learning by using mobile applications and Internet sources. They acknowledged that they could capitalize on Skype peer-tutoring sessions, chats of reflection and doubts, along with the peer-tutoring group web page to gain knowledge about the location of learning resources, to get access to those materials and applications of their interest, and to understand how to use them:

Due to the increased motivation for autonomous work other than tutorials, I have been interested in learning and studying more by myself, without taking into account the subject at university that assigns us additional work. I have used several tools that tutorials have provided me as links and videos. (P.2-Q2.

Another participant remarked:

Something even harder for me was to describe places and I think that autonomously I have focused on strengthen this aspect by explaining and audio-recording myself. I took advantage of the web-pages my tutor shared through Skype and I listened to and analyzed grammatically how the sentences were constructed and that has been one of the most important aspects in the development of my autonomous work. (P.3-45' 15')

The previous findings concur with Godwin-Jones' (2011) discussion on the innovative avenues for autonomous learning that the combination of growing online resources, network services, and educational software is offering. As shown in the previous excerpt, Internet tools encourage learning autonomy which, as Godwin-Jones mentions "is for the student to develop effective strategies for pursuing individual learning” (p. 4). The role of the teacher, or in the case of this study the peer-tutor, has also been highlighted in online environments as a support for students' autonomy. These facilitators' guidance is not only related to suggesting virtual resources (Godwin-Jones, 2011) but also promoting students' association with peers in communities (Evans \& Moore, 2013; Brooke, 2013), encouraging their recognition of learning and providing feedback (Brooke, 2013).

\section{Conclusions and Pedagogical Implications}

Two sets of findings contribute to understanding how a group of tutees' engagement in an online peer-tutoring model at a public university shaped their autonomous English learning. Firstly, data suggest a transformation in what these participants conceived as autonomy concerning English language learning. The tutees built more nuanced views of 
Luis Ignacio Herrera Bohórquez, José David Largo Rodríguez,

and John Jairo Viáfara González

self-directed learning in relation to self-discipline and associated traits, namely commitment and endurance. By delving into a model that provided them with tools to organize their autonomous work, search for options to fulfill their education needs, and exercise those language abilities of their interests, they started to think differently about what autonomy encompasses. Their upgraded conceptualizations also included the belief that autonomous learning was not necessarily an individual undertaking since the possibility of collaborating on online spaces with other tutees, in the emergent online community, was pivotal for them to rethink the role that shared limitations and mutual support can have in self-directed learning. Motivation became the third central element in the tutees' refreshed conceptualizations of autonomy. Apparently, having the opportunity to employ the online model as a source of language practice and research contributed to this renewed perspective.

Beyond their renewed conceptualizations, the tutees invested in their autonomous learning. Some of them claimed that the time they dedicated to self-directed learning increased. Motivation to learn and explore learning options more deeply became prominent reasons for these participants to devote more time to self-directed practices. Despite the fact that their university's expectation regarding students' autonomous work, five hours weekly for a three-credit course, is still higher than what participants detailed by the end of this study, the gains they claimed, so far, can be considered a favorable beginning to closing that gap.

By gaining awareness of the potential of target online environments, the model responded to the need detected by this study concerning the participants' scant understanding of how to take full advantage of Internet technologies for self-directed learning purposes. Overall, the tutees perceived that the model influenced their autonomy noticeably because it facilitated prompt support for obtaining feedback concerning their language learning queries. Likewise, not only did the model make it more convenient for the participants to access learning resources at any time and from any place, but also it provided abundant and innovative internet resources.

Considering this experience, we suggest that internet and all its applications, resources, and facilities should be integrated into online tutoring models rooted in a purposive and well-structured plan. Careful organization, monitoring, and training become the best way to mitigate risks that may emerge during implementation. Moreover, when asked in the final survey about the interaction between online and face-to-face peer-tutoring, all of the participants indicated that a hybrid model was the ideal support for their autonomy. This response leads us to consider as a further research endeavor the exploration of self-directed learning in peer-tutoring based on blended environments.

To close, the researchers strongly recommend that in order to implement any kind of blended-mediated pedagogical intervention, as has been suggested by the participants, 
universities not only are ready to make a substantial investment in the required technology, but also to ensure students' high accessibility to labs; thus, learners can explore all the possibilities that the internet may bring to their exploration of foreign languages as they engage in peer-tutoring.

Two additional topics for further research stem from these findings. Bearing in mind the participants' idea of undertaking peer-tutoring as a group dynamic potentiated by virtual environments, research on delving into the intricacies of autonomous learning as mediated by social interaction in these communities of learning is relevant. Likewise, the tutees' tendency to invest more effort in their autonomous learning in relation to some online applications (e.g. Skype tutoring) than in others which can permanently contribute to participants' understanding of self-directed learning dynamics (e.g. reflection chats) should be examined more deeply.

\section{References}

Álvarez, P. (2002). La función tutorial en la universidad. Madrid: EOS.

Ariza, J., \& Viáfara, J. (2009). Interweaving autonomous learning and peer-tutoring in coaching EFL student-teachers. Profile: Issues in Teachers' Professional Development, 11(2), 85-104.

Ary, D., Jacobs, L. C., Sorenson, C., \& Razavieh, A. (2008). Introduction to research in education ( $8^{\text {th }}$ Ed.). California, EU: Wadsworth Cengage Learning.

Benson, P. (2007). Autonomy in language teaching and learning. Language teaching, 40(1), 21-40.

Brooke, M. (2013). Facilitating the development of the autonomous language learner using online virtual learning environments. Theory and Practice in Language Studies, 3(4), 572-580. http://doi. org/10.4304/tpls.3.4.572-580

Cardozo, C. E. (2011). Tutoría entre pares como una estrategia pedagógica universitaria. Educ. Educ., 14(2), 309-325.

Cheng, Y. (2017). Cultivation of college students' autonomous English learning ability in IT environment based on project-based learning platform. Revista de la Facultad de Ingeniería, 32(9), 100-105.

Deci, E. L., \& Ryan, R. M. (1995). Human autonomy: Inefficacy, agency, and self-esteem. New York: Springer.

Dekhinet, R. (2008). Online enhanced corrective feedback for ESL learners in higher education. Computer Assisted Language Learning, 21(5), 409-425.

Dekhinet, R., Topping, K., Duran, D., \& Blanch, S. (2008). Let me learn with my peers online! Foreign language learning through reciprocal peer tutoring. Innovate: Journal of Online Education, 4(3), 1-9. 
Luis Ignacio Herrera Bohórquez, José David Largo Rodríguez, and John Jairo Viáfara González

Duran, D., \& Monereo, C. (2005). Styles and sequences of cooperative interaction in fixed and reciprocal peer tutoring. Learning and Instruction, 15(3), 179-199. http://dx.doi.org/10.1016/j. learninstruc.2005.04.002

Evans, M. J., \& Moore, J. S. (2013). Peer tutoring with the aid of the Internet. British Journal of Educational Technology, 44(1), 144-155.

Garrison, D. R. (1997). Self-directed learning: Toward a comprehensive model. Adult Education Quarterly, 48(1), 18-33.

Glaser, B., \& Strauss, A. (1967). The discovery of grounded theory: Strategies for qualitative research. Chicago: Aldine.

Glesne, C. (2006). Becoming qualitative researchers: An introduction ( $3^{\text {rd }}$ Ed.). Boston, MA: Pearson.

Godwin-Jones, R. (2011). Emerging technologies autonomous language learning. Language Learning \& Technology, 15(3), 4-11.

Holec, H. (1981). Autonomy and foreign language learning. Oxford: Pergamon.

Hubbard, P. (2008). CALL and the future of language teacher education. CALICO Journal, 25(2), 175-188. http://doi.org/10.11139/cj.25.2.175-188

Jones, R. H., Garralda, A., Li, D., \& Lock, D. (2006). Interactional dynamics in on-line and face-to-face peer-tutoring sessions for second language writers. Journal of Second Language Writing, 15, 1-23.

Kern, R., \& Warschauer, M. (2000). Introduction: Theory and practice of network-based language teaching. In M. Warschauer \& R. Kern (Eds.), Network-based language teaching: Concepts and practice (pp. 1-19). Cambridge: Cambridge University Press.

Little, D. (1991). Learner autonomy: Definitions, issues and problems. Dublin: Authentik Language Learning Resources Ltd.

Little, D. (2007). Language learner autonomy: Some fundamental considerations revisited. International Journal of Innovation in Language Learning and Teaching, 1(1), 14-29.

Liu, X. (2014). Influence of motivation, autonomy and online environment on listening skills of elementary and intermediate learners of English. International Education Studies, 7(7), 19-28.

Clarkson, B., \& Luca, J. (2002). Promoting student learning through peer tutoring - A case study. In P. Barker \& S. Rebelsky (Eds.), Proceedings of ED-MEDIA 2002--World Conference on Educational Multimedia, Hypermedia \& Telecommunications (pp. 1176-1181). Denver, Colorado, USA: Association for the Advancement of Computing in Education (AACE).

Miyakoda, H., Kaneko, K. I., Ishikawa, M., \& Shinagawa, N. (2010). Online multilingual vocabulary system and its application in L2 learning. International Journal of Cyber Society and Education, 3(1), 15-36.

Murphey, T., \& Jacobs, G. M. (2000). Encouraging critical collaborative autonomy. JALT Journal, 22, 220-244.

Nunan, D. (2003). Nine steps to learner autonomy. Symposium, 193-204.

Patton, M. Q. (2001). Qualitative evaluation and research methods. Thousand Oaks, CA: Sage Publications. 
Ryan, R. M., Kuhl, J., \& Deci, E. L. (1997). Nature and autonomy: An organizational view of social and neurobiological aspects of self-regulation in behavior and development. Development and Psychopathology, 9(4), 701-728.

Simpson, O. (2002). Supporting students in open and distance learning. London: Kogan.

Snodin, N. S. (2013). The effects of blended learning with a CMS on the development of autonomous learning: A case study of different degrees of autonomy achieved by individual learners. Computers \& Education, 61, 209-216. https://doi.org/10.1016/j.compedu.2012.10.004

Spratt, M., Humphreys, G., \& Chan, V. (2002). Autonomy and motivation: Which comes first. Language Teaching Research, 6(3), 245-266.

Sutrisno, D. (2016, May). Developing autonomous learning using web 2.0 in a digital age: Building language learners' content knowledge and improving writing skills. Paper presented at the 2nd international seminar on educational technology, Semarang, Indonesia.

Taylor, K. (2006). Autonomy and self-directed learning: A developmental journey. In C. Hoare (Ed.), Handbook of adult development and learning (pp. 196-218). New York: Oxford University Press.

Thurston, A., Duran, D., Cunningham, E., Blanch, S., \& Topping, K. (2009). International on-line reciprocal peer tutoring to promote modern language development in primary schools. Computers \& Education, 53(2), 462-472.

Tolosa, C., Ordóñez, C. L., \& Alfonso, T. (2015). Online peer feedback between Colombian and New Zealand FL beginners: A comparison and lessons learned. Profile: Issues in Teachers' Professional Development, 17(1), 73-86.

Tomes, N. (2001) Technology-supported collaborative learning. In N. Falchicov (Ed.), Learning Together-Peer Tutoring in Higher Education (pp. 275-291). London: Falmer.

Topping, K. J., Dehkinet, R., Blanch, S., Corcelles, M., \& Duran, D. (2013). Paradoxical effects of feedback in international online reciprocal peer tutoring. Computers \& Education, 61, 225-231.

Verba, M. (1998). Tutoring interactions between young children: How symmetry can modify asymmetrical interactions. International Journal of Behavioral Development, 22, 195-216.

Viáfara, J. (2014). EFL student teachers' learning in a peer-tutoring research study group. Colombian Applied Linguistics Journal, 16(2), 201-212.

Viáfara, J., \& Ariza, A. (2008). Un modelo tutorial entre compañeros como apoyo al aprendizaje autónomo del inglés. Ikala, Revista de Lenguaje y Cultura, 13(19), 173-209.

Warschauer, M., \& Liaw, M. (2011). Emerging technologies for autonomous language learning. Studies in Self-Access Learning Journal, 2(3), 107-118.

Wong, H. (2011). Enhancing learner autonomy in an on-line editing programme. Studies in SelfAccess Learning Journal, 2(3), 153-169.

Wong, J., \& Fauverge, A. (1999). Leverage - Reciprocal peer tutoring over broadband networks. ReCALL, 11(1), 133-142.

Wood, D., Bruner, J. S., \& Ross, G. (1976). The role of tutoring in problem solving. Journal of Child Psychology and Psychiatry, 17, 89-100. 